\title{
Family Perspective on Entrepreneurship
}

Discua Cruz, Allan

Basco, Rodrigo

\section{Introduction}

"Familia mea, meum fundamentum" (My family, my foundation) is a Latin phrase that heralds the fundamental importance of family for individuals. The relevance of family for entrepreneurship around the world is undisputed and hence merits close attention. In this chapter, we delve into the family perspective on entrepreneurship, which gravitates around three different yet interconnected research fields: family, entrepreneurship, and family business. Throughout this chapter we acknowledge the relevance of family for entrepreneurship in its different manifestations, from the creation, discovery and exploitation of an opportunity by individuals or teams, to the entrepreneurial behavior in established family businesses. By considering the inextricable connection of family and family business literature with entrepreneurship, we highlight previous and novel studies, interpret existing findings, and suggest a future research roadmap.

The connection of family and entrepreneurship is believed to be both ancient and persistent to date (Rosa, Howorth, and Discua Cruz 2014; Hoy and Verser 1994). The influence of family in entrepreneurship has been long considered to fit with the entrepreneurship literature (Westhead, Wright, and Ucbasaran 2001). Family is one of the fundamental reasons for individuals to engage in entrepreneurship (Johannisson 2003) and for family businesses to maintain, across family generations, the entrepreneurial spirit. A growing amount of studies published in top 
entrepreneurship journals and book compilations in the last decade highlight that entrepreneurship research is not shy to embrace a family perspective (Wiklund et al. 2011). Such heightened interest is manifested in four different areas: First, the way family is currently interpreted in entrepreneurship studies. Second, the interplay between a family perspective and the entrepreneurship phenomenon over time. Third, the theorizing process of a family perspective on entrepreneurship, which highlights its uniqueness in the entrepreneurship field. Finally, the family as a context for entrepreneurship. Based on this background this chapter delves into a family perspective on entrepreneurship.

This chapter highlights three schools of thought - entrepreneurship by families, embedded family entrepreneurship, and entrepreneurship across generations- which bring forward the complex interaction among family, entrepreneurship, and established family businesses. We use these schools of thought to explore and unveil a family perspective on entrepreneurship in three levels of analysis: individual, group/team, and business. The following sections in this chapter are based on a thematic review and synthesis of the literature and highlight the relevance of family and family business research before immersing into the schools of thought and levels of analysis.

\section{Overview of the phenomena of family, family business, and entrepreneurship}

\subsection{The field of family}

Families are seen as a basic and enduring unit of society (Smith et al. 2009). The study of families crosses the borders of several disciplines (multidisciplinary phenomenon). The family is an organization that cares for the maintenance of family life (sex, reproduction, economic affairs and education of young) and the ways in which families react and adapt to changing situations (Mckie, Cunningham-Burley, and Mckendrick 2005). Due to its importance, the field of family has received attention in a wide range of disciplines such as psychology, psychotherapy (von Schlippe, 
Schneewind, and Schneewind 2014), economics (Dew 2008), sociology, and organizational behavior (Eby et al. 2005), among others. To better understand the phenomenon of family, scholars call to acknowledge families as "intimate relationship systems" which impacts the way activities are approached by its members (Jennings, Breitkreuz, and James 2014; Jaskiewicz et al. 2017).

A systemic view of family highlights three perspectives: structural, psychosocial, and transactional (Koerner and Fitzpatrick 2004). The structural perspective focuses on family composition. The psychosocial task perspective emphasizes roles and tasks of family members. Finally, the transactional perspective focuses on the soft aspects related with family identity, emotional ties, and common expectations. These perspectives help understand basic demographic, functional and emotional aspects of family and entrepreneurship (Stangej and Basco 2017). Understanding families from a systems perspective provides a platform to untangle a connection with entrepreneurship.

A widely acknowledged theoretical umbrella to untangle the family phenomenon is the family system theory. Family system theory proposes a holistic perspective of family focusing on the relationships within members (von Schlippe, Schneewind, and Schneewind 2014). Under such lens, the interpersonal relationships within family boundaries and how these interpersonal relationships are developed defines the macro-systemic environment (the family as an institution) and the individual life of the participants in their cognitive, psychological, and physical development. This perspective is important as it provides the backbone for several organisational models (Olson 2000) as well as support general dimensions to understand families involved in specific activities, such as business and entrepreneurship.

The General System Theory suggests several interrelated aspects and features of families (von Schlippe, Schneewind, and Schneewind 2014) that are relevant for a family perspective on 
entrepreneurship. First, interactions among family members are based on a circular causality principle, that is, interactions are geared to create and nurture reciprocity. Second, interactions within the system may generate positive and negative feedback which may foster or paralyze family evolution. Third, implicit or explicit goals and objectives may be developed because of such interactions and create shared aims for the group and its members. Fourth, to achieve particular goals the family relies on rules, patterns, and routines which are formed over time based on members interaction. Fifth, an equifinality principle will show that there is no one particular way to achieve the same goals, and thus multiple paths are possible based on the interactions, circular causality, and feedback generated within the family context. Sixth, families are subject to balancing or misbalancing forces within the system (such as internal and external family shocks such as. marriage, death, births). Thus the system may display homeostasis and heterostasis features respectively. Seventh, the family system has the ability to reproduce its elements for nurturing and reproducing itself (autopoiesis feature). Finally, the boundaries within the family (that is, among individuals) determine the limits between the family and its environment.

While a complete review of the family field is beyond the objective of this chapter, it is crucial to note that the family system theory has been the main theory applied to understand the relationships that emerge between a family and a business system. Studies focusing on a systemic view of a family may aim to describe, understand, and predict the relevance of family as a group of individuals as well as the cause and effect of individuals being members of a family. Such view is important as family dynamics are likely to influence family-based economic activities over time. Thus, the family field provides a first step to understand a family perspective on entrepreneurship.

\subsection{The field of family business}


Understanding the family business field is relevant for a family perspective on entrepreneurship because it is in the family business phenomenon where family and business logics collide (Basco 2017d). While family businesses have existed for a long period of time and are an outcome of entrepreneurship, defining them is difficult (Howorth et al. 2010). A widely accepted definition poses that a family business is "a business governed and/or managed with the intention to shape and pursue the vision of the business held by a dominant coalition controlled by members of the same family or a small number of families in a manner that is potentially sustainable across generations of the family or families." (Chua, Chrisman, and Sharma 1999, 25). The family business field has lacked theoretical underpinnings as researchers efforts focused on gaining legitimacy among mainstream academic fields (Pérez Rodríguez and Basco 2011). Therefore, the field mainly focused on the phenomenon of family business by bringing and applying, from stablished academic fields, potential theories to understand, interpret, and predict it (for a literature review about main stream theories applied to family businesses see: Siebels and zu KnyphausenAufseß 2012).

Thus the family business field has been closer to the practitioner experience since its inception. A systemic view would suggest that in a family business the borders between a family and business systems are often blurred, with individual and diverse resources flowing from one system to another (Litz 2008). In this sense, the field of family business focuses on the family effects on the organization in three different levels: individual level, successful successor development (Lansberg and Astrachan 1994)), group level (communication among family and non-family members (Distelberg and Blow 2010)), and firm level decision-making (Basco and Pérez Rodríguez 2011)). 
To date, several literature review articles (e.g., Basco 2013; Perez Rodriguez and Basco 2011; Chrisman et al. 2010) analyze the evolution of the field. While the family business field has evolved at the expense of cross fertilization of ideas from different academic fields (such as psychology, marketing, management, strategy, and business economics among other) applied to the phenomenon, the family system theory has fertilized the field of family business because its fundamentals have been extending to re-interpret theories that come from different academic fields. That is, any theoretical reinterpretation applied to the family business phenomenon has been approached with the assumption that overlapping systems in a family business (for instance family, ownership, and management) represents the nature of family businesses. For instance, a reinterpretation of agency theory in the context of family businesses highlights family agency problems such as nepotism, altruism (Lubatkin et al. 2005) and goal alignment (Basco and Calabrò 2017). Stewardship theory reinterpretation has highlighted the pro-organizational behavior of family business members linked to the welfare to the firm (Davis, Allen, and Hayes 2010). Stakeholder theory reinterpretation has highlighted the particular goals that family businesses pursue and identified clearly who may be influenced by such pursuits (Basco 2017d). A summary of theories that highlight the interaction of the family, enterprise and family business fields is presented in the following sections.

\subsection{The field of family Entrepreneurship - A Prelude}

A family perspective on entrepreneurship supports the view that entrepreneurship is inextricably linked to family (Aldrich and Cliff 2003; Heck et al. 2006). Families are heterogeneous organizations with interconnected lives, norms, and values, that approach the entrepreneurial processes based on deeply rooted connections (Stamm 2016). In this context, a family perspective on entrepreneurship supports the view that economic activities, originating from entrepreneurial 
pursuits, might be "embedded in family relationships rather than family relationships embedded within economic activities" (Stewart 2003, 388). Family dynamics and family life cycles are often perceived to be "the oxygen that feeds the fire of entrepreneurship" (Rogoff and Heck 2003). Aldrich \& Cliff (2003) claim that family changes, transitions, resources and norms influence entrepreneurship on three relevant aspects: a) a considerable proportion of new businesses are founded by two or more related individuals; b) the founding of a firm may represent responses to changing family relationships or a way to handle family or business life cycles rather than outcomes of the rational assessments of discovered economic opportunities such as marriages, birth, divorce, death; c) during the start-up process of a venture, family involvement plays an important role in the mobilization and provision of diverse resources for individual entrepreneurs.

Therefore, a family perspective on entrepreneurship acknowledges:

- The natural life cycle of families (Danes 2014). Entrepreneurship is influenced by the support that family can provide over time (Jennings, Breitkreuz, and James 2014).

- The family as a resource provider of physical, emotional, and material resources for entrepreneurship (Stewart 2003). That is, an incubator for entrepreneurs and nascent ventures sharing resources such as building and equipment (Clarysse et al. 2005), emotional connections (Steier 2007), closely-knit relationships and obligations (Stewart 2003), interest-free loans, assets, and inexpensive labour as well as access to business related acquaintances and specialized knowledge (Anderson and Miller 2003; Stewart 2003).

- The family embedded in the entrepreneurial process ( Aldrich and Cliff 2003; Shepherd 2016; Hamilton, Discua Cruz, and Jack 2017). 
- The family business as a context where entrepreneurship is engaged throughout time (Howorth, Jackson, and Discua Cruz 2014; Basco 2014) encouraging new ideas, spin-off access to space in existing buildings, existing machinery or technology, and markets if it is feasible (Aldrich, Renzulli, and Langton 1998).

- A family perspective on entrepreneurship also considers the family business as a context where family conflicts may also affect the entrepreneurial process (von Schlippe and Frank 2013; Nicholson 2015). Danes and Morgan (2004) highlight that conflicts related to work/family life balance, unfair distribution of resources (money, time, energy) between family and business systems may create increasing tensions. Nicholson (2015) advocates that there are different conflict dynamics that lurk in the context of families that engage in entrepreneurship which make them extremely sensitive to conflicts such parent-offspring conflict, affinal bonds and sibling rivalry. Von Schlippe and Frank (2017) pose that as family members engage in the entrepreneurial process, emotional arenas may develop as the pressures of engaging in creating and subsequently manage a business venture may put pressures in family members involved over time.

Thus, a family perspective on entrepreneurship embraces the relevance of family as a fundamental social unit, with unique relational systems that can support but also affect entrepreneurship. In the next section we explore the diverse schools of thought that frame a family perspective on entrepreneurship

\section{Organizing knowledge: Schools of thought}

This chapter identifies three schools of thought around the family perspective on entrepreneurship: enterprising families, family embeddedness, and transgenerational entrepreneurship. Table 1 shows the general information of each school of thought, highlighting aims and main concepts, 
approach, level of analysis, assumptions, limitations and selected works. Our analysis shows overlaps and differences among these schools of thought.

Overall, the schools of thought position entrepreneurship as the anchor to rationalize the phenomenon of study and follow similar research strategies in the theorizing process. That is, entrepreneurship becomes the gravity center where the orbiting research strategies are characterized by incorporating family dimensions and family variables into the study of entrepreneurship. This process of theorizing has followed a "borrowing and replicating" (i.e., existing entrepreneurship research is replicated by using family business samples) and "borrowing and extending" (i.e., the replication is extending by incorporating family and family business variables into entrepreneurship as phenomenon of study) research strategies (Perez Rodriguez et al. 2011).

Each school of thought can be understood by: a) the level of analysis, such as individual, group, and firm-family level; b) dimensions, such as types of family and family business dimensions that are incorporated into the analysis, and c) relationships, namely the connections and associations among family and family business dimensions and variables that affect entrepreneurship. For instance, while the "Enterprising Family Perspective" is mainly focused on family involvement as an antecedent of family wealth creation and firm wealth creation (Carter 2011; Rubin 2005), the "Family Embeddedness Perspective" incorporates family dimensions to explain a traditional view of entrepreneurship such as new venture creation (Rodriguez, Tuggle, and Hackett 2009). The "Entrepreneurship across Generations", assuming that families in business have a special mindset for business growth and strategic entrepreneurial behavior, focuses on family dimensions that affect habitual entrepreneurship by families in business (Rosa et al., 2014) and corporate 
entrepreneurship in the context of family businesses - transgenerational entrepreneurship (Basco, Calabrò, and Campopiano 2018).

Table 1 shows that there is a greater emphasis on a phenomenological driven research approach. There is a limited focus on theoretical driven approaches (such aspect highlights the use of "borrow/replication" and "borrow/extending" approaches as strategies for knowledge development. Moreover, the schools of thought identify and use theories from other fields to position and frame their analytical stance. Mainstream theories at the firm level, such identity theory (Memili et al. 2010), are used to introduce family dimensions in the analysis of the interconnectivity between family, entrepreneurship and family business.

--- Insert Table 1 around here ---

The next subsections explore the individual, group/team, and firm level of influence of a family perspective in entrepreneurship.

\subsection{The individual level}

The evidence linking family and entrepreneurship is well documented at the individual level of analysis. The predominant school of thought at this level is embodied in the work of Aldrich and Cliff (2003), who propose the idea of family embeddedness to highlight how family dynamics influence the initial steps in an entrepreneurial process. It is at this level of analysis where the family field has penetrated the fields of family business and entrepreneurship because it assumes that individuals play an important role by cross-fertilizing ideas, behaviors, and, expectation within the blurred boundaries of the family, business, and entrepreneurship systems. That is, form the interaction of family members, their rules, goals, patterns of behaviors family affect the way individual behave as entrepreneur within the context of the firm or just by starting up their own 
economic initiatives. For instance, recent findings suggest that a structural perspective of the family such as family demographic (Rodriguez, Tuggle, and Hackett 2009), a psychosocial perspective of the family such as role distribution (Pieper 2010) and a transactional perspective of the family such as kinship tie (Alsos, Carter, and Ljunggren 2014) affect entrepreneurship.

From a structural perspective, the birth order affects sibling personality because of their competition for their niche within the family and consequently may determine their entrepreneurial behavior. That is, how they discover and create entrepreneurial opportunities and exploit them. Family is a source of diverse resources that individual family members can use to start or acquire a new venture (Anderson, Jack, and Dodd 2005). As family relationships become embedded over time, the structure of a family can contribute with both tangible and/or intangible resources at different points in time. Tangible items revolve around the provision of funds (e.g. interest-free loans), physical assets (e.g. land, plant, equipment), and/or time and skills at low costs if necessary (Stewart 2003). Access to financial capital, considered a critical resource, is often first acquired within family networks or through their support (Jack 2005). Other, intangible resources such as socialization into networks linked to family status and social class provides a starting point for many entrepreneurs (Anderson and Miller 2003). Family relationships can provide access to business-related connections. When members of a family are involved in business then relationships in diverse networks can provide heterogeneous information, specialized knowledge and other resources for nascent entrepreneurs (Stewart 2003). Resources such as information about local markets, suppliers, employees, relevant institutions and potential first customers can be accessed through extended family members in business (Jack 2005). Dyer, Nenque, and Hill (2014) highlight such resources under a "family capital" umbrella. The family capital perspective highlights that family influenced resources are difficult to imitate, can be mobilized quickly, have 
low transaction costs, and can be transferred efficiently across generations. Yet, while the relevance of family structure is uncontested in the provision of resources particularly in the initial entrepreneurial steps prior studies suggest it may later turn into a liability (Church 1993).

Second, from a psychosocial perspective, the support of family in the acquisition of education, skills and mental models is important for entrepreneurship. Rogoff and Heck (2003) highlight that entrepreneurs rely on different skills and traits linked to formal education in higher institutions or vocational schools. When individuals are members of a family that owns a business, members can develop specific knowledge of industries, technologies and markets which may influence the entrepreneurial journey (Carr and Sequeira 2007; Davidsson and Honig 2003) of family members. Furthermore, individuals who have participated in existing family businesses have most likely been exposed to an entrepreneurial culture that has shaped, often unintentionally, mental models, heuristics and an approach to engaging in business activities. The familial status, professional aspirations, and entrepreneurial performance of one family member may have powerful consequences for the career choices of other family members (Stamm 2016). Notwithstanding, Nicholson (2015) warns that while family support is crucial for entrepreneurial intentions, family tensions such as negative affective relationships, sibling rivalry, emotionally charged interpersonal clashes between family generations, and perceptions of unfairness may hinder support for an entrepreneurial career. When negative emotional relationships between family members escalate then a detrimental effect towards support of entrepreneurial objectives may be observed (Kidwell, Hoy, and Ibarreche 2012). On the other hand, the parental style (authoritative, authoritarian, and persuasive) affects individual behavior and personality, and specifically their entrepreneurial competences (Schmitt-Rodermund 2004) 
Third, from a transactional perspective, one of the key features of the family effect in entrepreneurship gravitates around the relationships that can influence the entrepreneurial process over time. Trust may be most embedded in families. Family ties are supposed to be stronger and more enduring in the business context because they are based on trust, sentiments and emotions (Hoffman, Hoelscher, and Sorenson 2006). Trust among family members provides advantages related to emotional encouragement, support in times of crisis, and unity with trusted individuals in alien and hostile environments (Kaslow 1993). The development of kinship ties within the family structure (in the nuclear and extend family) is a necessary condition to support activities such as initial discussions about a business idea, the willingness to provide support and resources or to procure information, resources or expertise outside family circles. Such approach appeals to the closely knit nature of families and the importance given to emotions in transaction exchanges between family members (Stewart 2003). Where such transactions often transcend time and place

and relate to both extended structural aspects as well as distant yet latent psychological aspects of families across countries we find the nascent and often overlook nature of diaspora families, whose structural, psychosocial and transactional features facilitate entrepreneurial efforts across cities, regions and nations (Elo and Hieta 2016).

\subsection{The group/team level}

Until recently, the bulk of entrepreneurship research around a family perspective in entrepreneurship focused on individual entrepreneurs. Yet, the relevance of collective forms of entrepreneurship influenced by family cannot be overlooked (Johannisson 2003). Scholars have challenged the mythic stand-alone characteristics and approach of the individual entrepreneur and argue that several individuals, acting as a team, could also engage in the entrepreneurial process (Wright and Vanaelst 2009) - collective entrepreneurial mind-set (Shepherd and Patzelt 2017). 
Interpreting the family through the lenses of system theory, that is through the interactions of family members and the circular causality by creating collective rules, patterns, goals and expectation, may affect group/team dynamics given that relationships between group members are both "personal and professional" (Dyer 2003, 409). Family or kinship liaisons are a strong bonding agent in teams; it can create higher cohesion, potency, reduction in task conflicts, and shared strategic consensus (Ensley and Pearson 2005). The intricate relationships between a set of family members that engage in entrepreneurial activities, ranging from creating new businesses to developing new products or services in existing organizations has not gone unnoticed (Iacobucci and Rosa 2010). At the group level system theory has been used to interpret and re-interpret the use of mainstream theories such as human capital, RBV, stewardship theory, as well as LMX (leader-member exchange) provide a relevant theoretical framework at this level (Discua Cruz, Hadjielias, and Howorth 2017).

To date, a collective perspective of family in entrepreneurship has received attention through the study of entrepreneurial and entrepreneuring families (Nordqvist and Melin 2010; Uhlaner et al. 2012), entrepreneurial teams composed of family members (Schjoedt et al. 2013) and families in business (Hamilton et al., 2017). To begin, entrepreneurial teams composed of family members are not new. The most common entrepreneurial team or entrepreneurial family type is a husband and wife in business. Entrepreneurial teams composed of family members are implicitly present in the foundation of many enterprises around the world (Chrisman, Chua, and Steier 2003; Ucbasaran et al. 2003). The study of family members as a team highlights the relevance of concentrating on subgroups of family members (Uhlaner 2006). Entrepreneurial teams composed of family members portray particular characteristics: They may resemble a team with prior joint experience (Ucbasaran et al. 2003); may focus on a collective long term view and the 
intergenerational outlook of a family (Nordqvist and Melin 2010). Furthermore, their comparative advantage may lie on strong trust among members and an entrepreneurial culture forged over time through which individual family members reinforce their identity as entrepreneurs, reduce transaction costs and facilitate a shared approach to entrepreneurship (Discua Cruz, Hamilton, and Jack 2012).

Recently, a family entrepreneurial team (FET), defined as "two or more family members, related by kinship or marriage, who engage in the identification and pursuit of business opportunities to establish or purchase a firm, have an equity stake in the firm, and have a direct influence on the strategic choice of the firm at the time of founding“" (Discua Cruz, Howorth, and Hamilton 2013, 20) represents a form of intrafamily entrepreneurship, that is, entrepreneurship by families in business and in the context of existing family businesses. FETs may be geared around a stewardship perspective, which helps explain the behavior of family members minimizing the pursuit of individual's interests and looking after the common good of the family business (Davis, Allen, and Hayes 2010). Entrepreneurial stewardship underscores a collective commitment to build existing assets or products within an existing organization (Vega Solano and Discua Cruz 2017) or the creation of diverse ventures over time that cater for the need of various family members (Michael-Tsabari, Labaki, and Zachary 2014). Such collective approach highlights the influence of a family perspective on entrepreneurship across generations.

As many areas of entrepreneurship, the topic of family entrepreneurial teams, entrepreneurial and entrepreneuring families and families in business is still in its infancy. Ucbasaran et al. (2003) warn of reduced cohesion and increased conflict as a result of family members forming a team to pursue opportunities as dominance by individual members with substantial experience over others with less experience may hinder the process. In a team formed by members of two generations of 
a family in business, succeeding family members may lack the entrepreneurial drive that existed in a founding generation (Westhead et al. 2001). Experienced family members could potentially dominate the process leading the development of specific interest in business at the expense of objectives and interests of other family members. Furthermore commitment and loyalty can be expected to be quite varied by family members (Van Auken and Werbel 2006; Sharma and Irving 2005). The diversity of FETs can be as varied as the diversity of objectives pursued by family members (Discua Cruz, Hadjielias, and Howorth 2017). While some FETs may concentrate on the strategic renewal of one firm throughout time, others may go about setting up diverse ventures in sequence or in parallel, at the same time while some may prefer to continue as a tight unit others may reshuffle their composition based on family dynamics or disband due to latent and unaddressed tensions.

\subsection{Business Level}

Entrepreneurship research incorporated the firm level when scholars began exploring entrepreneurial activities within an organization. This is often studied under the concept of corporate entrepreneurship. Corporate entrepreneurship is the set of activities carried out within an existing organization to create a new firm (corporate venturing), to engage in strategic renewal, and/or to innovate existing organizations (Sharma and Chrisman 1999). Recently, corporate entrepreneurship has been integrated into family business research as a particular way in which family businesses are able to survive - transgenerational family businesses.

The interaction between family business and corporate entrepreneurship attempts to decode the family effect on corporate venturing, renewal strategies, and innovation. This research line emerged because family participation in the firm (family members involvement in ownership, governance, and management arenas) affects the way an organization creates, develops, and 
allocates resources (Cucculelli et al. 2014) and strategically compete (Basco 2014) because of the set of specific goals, priorities, and interests brought by family members into the firm (Basco 2017d). This line of thought was transferred to corporate entrepreneurship research to account for a family effect. In this context, studies have focused on explaining: 1) to what extent family dimensions affect corporate entrepreneurship and 2) to what extent family dimensions moderates the relationship between corporate entrepreneurship and firm performance.

First, regarding the family effect on corporate entrepreneurship, this line of research has been the most common path to link the research of family, family business and entrepreneurship. Scholars have theorized about the direct impact of family variables on entrepreneurial orientation (e.g., Garcés-Galdeano et al. 2016; Sciascia et al. 2015), searching for opportunities (Patel and Fiet 2011), or business growth (Alsos, Carter, and Ljunggren 2014). Yet, the family effect studied in corporate entrepreneurship is often reduced to a set of few family variables (e.g., a dichotomy of family vs. non-family businesses, family ownership and family management and generational involvement).

By considering the differences between family businesses versus non-family businesses, comparative studies were the most basic research technique at the family-firm level. Most research at this level is exploratory in nature, phenomenological driven, and mainly built on the assumption that different types of ownership, management, and governance shape decision making specifically corporate entrepreneurship behavior. Even though the distinction between family and non-family businesses showcased differences in firm behavior, findings are limited in explaining why the differences among firms emerged. Extending this perspective in order to overcome this limitation, an additional group of studies argued that family businesses are not homogenous and conjectured that the heterogeneity of family businesses matter. In this sense, studies introduced 
different variables to capture family business heterogeneity such as varying degree of family involvement or generational participation (Kellermanns and Eddleston 2006).

Therefore, because of contradicting findings about the direct effect of family variables on corporate entrepreneurship, the most promising research path is the one that combines the family effect on entrepreneurial behavior with additional internal and external dimensions. Regarding the internal dimensions, an incipient line of research is being developed by introducing a behavioral perspective (Sciascia et al. 2015). For instance, the effect of non-economic goals and knowledge transformation linked to generational stages (Patel and Fiet 2011) on corporate entrepreneurship. Regarding the external dimensions, to understand further the relationship between family and entrepreneurship, scholars called to look closely into the context families and the environment in which firms dwell and operate. For instance, while Au and Kwan (Au and Kwan 2009) showed that "Chinese entrepreneurs seek initial funding from their family rather than from outsiders only if they expected lower transaction costs and lower levels of family interference in the business", Khavul, Bruton, and Wood (2009) showed that for East African entrepreneurs strong family and community ties are important in the creation and development of firms. In the case of minority groups in particular contexts (e.g., Hispanic communities in the US) (see Fairlie and Robb 2007) family social capital was an important aspect for entrepreneurs to feel prepared to tackle on the entrepreneurial process and take the first step towards new venture creations (Chang et al. 2009).

Second, regarding the moderating effect of family variables (e.g., generational involvement and family commitment), this research line has been an extension of the previous one which measure the direct relationship. Several studies used family moderating variables on the relationship between corporate entrepreneurship and firm performance (Boling, Pieper, and Covin 2016) and confirmed the moderator effect of family variables (at individual level or family-firm level) 
(Marchisio et al. 2010). This research stream incorporates family variables to contextualize the entrepreneurship phenomenon.

In sum, the theorizing process of the intersection between family, family business, and entrepreneurship follow a "borrow and replication" strategy in which mainstream theories, concepts and relationships are applied to a family business sample and a "borrow and extending" strategy which attempts to go beyond the previous strategy by adding, and therefore, extending, the current knowledge with family dimensions, relationships, and explanations. However, the accumulation of knowledge by using "borrow and replication" and "borrow and extending" strategies have brought researchers to extend their aspirations to the third stage of theory-building process: inverse contribution, when new knowledge challenges and transforms the field core and the related disciplines (Perez Rodriguez et al. 2011). Few exceptions move the research into a more elaborate theoretical level (e.g. Alsos, Carter, and Ljunggren 2014). For instance, a recent study authored by Jaskiewicz, Combs, and Rau (2015) theorized that entrepreneurial legacy, family's rhetorical reconstruction of past entrepreneurial achievement or resilience, motivates incumbent and next-generation owners to engage in strategic activities that foster transgenerational entrepreneurship.

\section{Future research}

The particular and unique pattern of knowledge development and theory-building process in the interaction of family, family business, and entrepreneurship research has shown the embeddedness and connections between them in three different levels. Even though unpacking these relationships has brought a new understanding of the phenomenon of family perspective on entrepreneurship, it is possible to suggest some new avenues for future research. 
First, a long standing gravity center in entrepreneurship has been identified. That is, scholars incorporated family and family business dimensions in the field of entrepreneurship in order to extend the understanding of the entrepreneurship phenomenon in its different manifestations. However, the development of the family entrepreneurship phenomenon can benefit from a more balanced approach (for instance see the model developed by Stangej and Basco 2017). That is, we wonder if there is a new phenomenon of study called family entrepreneurship that unifies theories and approach by blending ideas form family, family business, and entrepreneurship literature.

Second, another particular path to enhance knowledge is to look into the different levels of analysis by incorporating a balanced perspective between family and entrepreneurship. At the individual level the tension in the relational tradeoffs between members of a family offers ample ground for further research (Stamm 2016), for instance by investigating how emotions and affect influence the entrepreneurship process (Shepherd 2016). Incorporating such tensions in our studies can reveal important and hidden aspects in the level of resource access and provision during the entrepreneurial process, shedding some light into the complex process leading to firm creation and the effects of family dynamics. At group level, further understanding of family dynamics at the individual and collective level may also help explain the development of a network of businesses over time (Rosa, Howorth, and Discua Cruz 2014). Finally, at the family-firm level, the lack of theory to predict corporate entrepreneurship behavior in the context of family businesses calls for further exploration. At all levels, further qualitative research may overcome the constraint that replication research strategies entail. Whilst each level has different evolution paths, there is a lack of studies observing the entrepreneurship phenomenon by integrating multiple levels of analysis. Future studies should explore the dimensions of family system theory (interactions, circular 
causality, goals, rules, patterns, equifinalisty, heterostasis, and autopoiesis) and their aggregate and disaggregate effect across level to configure implications for entrepreneurship.

Third, beyond the three levels of analysis, there is an alternative level which has been largely overlooked in the intersection between family, entrepreneurship, and family business: the regional level. This has remained a largely unexplored level. There are already some efforts to link family business and regional development (Basco 2015; Stough et al. 2015) and family business entrepreneurship at the regional level, yet further theorizing efforts of the interaction of family, entrepreneurship, and family business is needed at regional context. The main question to explore at this level is to better understand the role that family entrepreneurship phenomenon plays for social and economic growth and development.

Fourth, further understanding of the family entrepreneurship phenomenon in diverse contexts is needed. That is, following system theory, it is important to understand the boundaries among individual (private and social life) within the system but the boundaries among systems in which individual participate. The dynamics of family, entrepreneurship, and family business need also to take into account the cultural diversity around the world by using a multiple embeddedness context approach for entrepreneurship (Basco 2017a; Gupta and Levenburg 2010; Basco 2017b). Such diversity highlights the different views of family and the perceptions of enterprise over time. In some contexts the entrepreneurial process may be easier to start in the context of family due to the family resources when family relationships are positive and particularly where institutional requirements may entice nascent entrepreneur to access the family resource pool (Khavul, Bruton, and Wood 2009). On the other hand, there may exist particular environments where cultural, economic, and institutional forces may constrain family-based entrepreneurial activities (Ivanova 
2009). A similar approach could be extended to the study of corporate entrepreneurship study in family businesses where contextual forces retard or expand business growth and development.

Fifth, as previous sections have detailed, there is no theory of family perspective on entrepreneurship. Such lack of theory is related to the notion that the family entrepreneurship phenomenon has been built upon mainstream theories and approaches already used in the context of entrepreneurship (such as organizational, strategic, economics, and behavioral fields), the phenomenological stage of family business research, and the limited exploration of family itself (the limited participation of scholars from the field of family). Therefore, future research in analyzing the family perspective on entrepreneurship should look for more independence from the field of entrepreneurship, more focus on strategies to build theory, and more implication of researchers paying attention to the family side in order to bring new ideas and different lenses.

Finally, the study of family perspective on entrepreneurship cannot avoid time as particular dimensions linked to individual and family life cycle. Future research should go beyond the time as objective dimension (a progressive chronology of events that happen each other - birth, survive, exit) to a subjective dimension in order to capture the meaning of time for peoples and cultures which may affects entrepreneurship. Subjective dimension that mirrors the present of entrepreneurship behavior (at individual, group, and firm levels) with the time-space framework to understand the past and how future expectations are shaping.

--- Insert Table 2 around here ---

\section{Concluding thoughts}

This chapter aimed to bring forward a family perspective on entrepreneurship. In this sense, there is a need to continue exploring the influence of family dynamics on entrepreneurship. Neglecting 
the effect of family on entrepreneurship can only ever be a partial representation of reality. A family perspective on entrepreneurship, as a sub-multidisciplinary field of research, may have theoretical and practical implications. A family perspective on entrepreneurship can shed new light in mainstream fields (family, entrepreneurship, and family business) by interconnecting knowledge but at the same time become a platform for developing a more integrative theory of family-based organizational and entrepreneurial activities. Moreover, a family perspective on entrepreneurship can expand the interpretation that practitioners and policymakers have regarding the family as economic and social actors. Even though family-based organizations and entrepreneurial activities are the backbone of local economies (Howorth, Jackson, and Discua Cruz 2014), family and family business have been neglected from regional economic policies (Basco and Bartkeviciute 2016). Understand the relationship between family, entrepreneurship, and family business within geographical spaces is important to develop polices that stimulate regional development through recognizing the specificities of economic and social actors.

There are three areas where further development is warranted. First, in the individual, group/team, and firm-family levels, where the intersection of family, entrepreneurship family business occurs. Second, an "inverse contribution strategy" is necessary in order to gradually reduce the dependence on mainstream theoretical lenses. This would allow to theorize and incorporate family knowledge into the multidisciplinary field of entrepreneurship. Third, the phenomenon of family perspective on entrepreneurship, would benefit from further acknowledgement of context (Welter 2011). While the family context is relevant to study entrepreneurship, little is known about how it can help explain the multiplicity of contexts in which entrepreneurship happens (Basco 2017a; Basco 2017c). This chapter highlights that while most studies to date have focused on single 
contexts or localities, a family perspective on entrepreneurship could be explored across cultures and regions (Basco 2015). 


\section{References}

Aldrich, Howard E, and Jennifer E Cliff. 2003. "The Pervasive Effects of Family on Entrepreneurship: Toward a Family Embeddedness Perspective." Journal of Business Venturing 18 (5): 573-96.

Aldrich, Howard E, L Renzulli, and N Langton. 1998. "Passing on Privilege: Resources Provided by Self-Employed Parents to Their Self-Employed Children.” In Research in Social Stratification and Mobility, edited by K Leicht, 291-318. Greenwich, CT: JAI Press.

Alsos, Gry Agnete, Sara Carter, and Elisabet Ljunggren. 2014. "Kinship and Business: How Entrepreneurial Households Facilitate Business Growth." Entrepreneurship \& Regional Development 26 (1-2). Routledge: 97-122.

Anderson, Alistair R, S L Jack, and S D Dodd. 2005. "The Role of Family Members in Entrepreneurial Networks: Beyond the Boundaries of the Family Firm." Family Business Review 18 (2): 135-54.

Anderson, Alistair R, and Claire J Miller. 2003. “"Class Matters': Human and Social Capital in the Entrepreneurial Process." The Journal of Socio-Economics 32 (1): 17-36.

$\mathrm{Au}$, Kevin, and Ho Kwong Kwan. 2009. "Start-Up Capital and Chinese Entrepreneurs: The Role of Family." Entrepreneurship Theory and Practice 33 (4): 889-908.

Basco, Rodrigo. 2013. "The Family's Effect on Family Firm Performance: A Model Testing the Demographic and Essence Approaches." Journal of Family Business Strategy 4 (1): 42-66.

. 2014. "Exploring the Influence of the Family upon Firm Performance: Does Strategic Behaviour Matter?" International Small Business Journal 32 (8): 967-95.

_ 2015. "Family Business and Regional Development. A Theoretical Model of Regional Familiness." Journal of Family Business Strategy 6 (4): 259-71.

- 2017a. "Epilogue: Multiple Embeddedness Contexts for Entrepreneurship." In Contextualizing Entrepreneurship in Developing and Emerging Economies, edited by Marcela Ramírez-Pasillas, Ethel Brundin, and Magdalena Markowska, 329-36. London: Edward Edgar. . 2017b. "Epilogue: The Multiple Embeddedness of Family Firms in the Arab World." In Family Businesses in the Arab World: Governance, Strategy, and Financing, edited by Sami Basly, 247-56. Cham: Springer International Publishing.

_. 2017c. "The Multiple Embeddedness of Family Firms in Arab World." In Family Businesses in the Arab World - Governance, Strategy, and Financing, edited by Sami Basly, Paul-Laurent Saunier, and Alaya Marouane, forthcoming. . 2017d. “'Where Do You Want to Take Your Family Firm?' A Theoretical and Empirical Exploratory Study of Family Business Goals." BRQ Business Research Quarterly 20 (1): $28-44$.

Basco, Rodrigo, and Inga Bartkeviciute. 2016. "Is There Any Room Form Family Business into 
European Union 2020 Strategy? Family Business and Regional Public Policy." Local Economy 31 (6): 709-32.

Basco, Rodrigo, and Andrea Calabrò. 2017. "Who Should Sit There? Effects of Family-Oriented Objectives on Board Composition." International Journal of Entrepreneurial Venturing 9 (1): 89-99.

Basco, Rodrigo, Andrea Calabrò, and Giovanna Campopiano. 2018. "Transgenerational Entrepreneurship around the World: Implications for Family Business Research and Practice." Journal of Family Business Strategy, forthcoming.

Basco, Rodrigo, and María José Pérez Rodríguez. 2011. "Ideal Types of Family Business Management: Horizontal Fit between Family and Business Decisions and the Relationship with Family Business Performance.” Journal of Family Business Strategy 2 (3): 151-65.

Boling, J. Ruben, Torsten M. Pieper, and Jeffrey G. Covin. 2016. "CEO Tenure and Entrepreneurial Orientation Within Family and Nonfamily Firms." Entrepreneurship Theory and Practice 40 (4): 891-913.

Carr, Jon C, and Jennifer M Sequeira. 2007. "Prior Family Business Exposure as Intergenerational Influence and Entrepreneurial Intent: A Theory of Planned Behavior Approach." Journal of Business Research 60 (10): 1090-98.

Carter, Sara. 2011. "The Rewards of Entrepreneurship: Exploring the Incomes, Wealth, and Economic Well-Being of Entrepreneurial Households." Entrepreneurship Theory and Practice 35 (1): 39-55.

Chang, E P C, E Memili, J ames J Chrisman, F W Kellermanns, and J H Chua. 2009. "Family Social Capital, Venture Preparedness, and Start-Up Decisions A Study of Hispanic Entrepreneurs in New England." Family Business Review 22 (3): 279-92.

Chrisman, James J, Jess H Chua, and Lloyd P Steier. 2003. "An Introduction to Theories of Family Business." Journal of Business Venturing 18 (4): 441-48.

Chrisman, James J, F W Kellermanns, K C Chan, and K Liano. 2010. “Intellectual Foundations of Current Research in Family Business: An Identification and Review of 25 Influential Articles." Family Business Review 23 (1): 9-26.

Chua, Jess H, James J Chrisman, and Pramodita Sharma. 1999. "Defining the Family Business by Behaviour." Entrepreneurship Theory and Practice 27 (4): 19-39.

Church, Roy. 1993. "The Family Firm in Industrial-Capitalism - International Perspectives on Hypotheses and History." Business History 35 (4): 17-43.

Clarysse, Bart, Mike Wright, Andy Lockett, Els Van de Velde, and Ajay Vohora. 2005. "Spinning out New Ventures: A Typology of Incubation Strategies from European Research Institutions." Journal of Business Venturing 20 (2): 183-216.

Cucculelli, Marco, Lidia Mannarino, Valeria Pupo, and Fernanda Ricotta. 2014. "OwnerManagement, Firm Age, and Productivity in Italian Family Firms." Journal of Small Business Management 52 (2): 325-43. 
Danes, Sharon M. 2014. "The Future of Family Business Research Through the Family Scientist's Lens.” In The SAGE Handbook of Family Business, 611-19. Thousand Oaks, CA: Sage Publications.

Davidsson, Per, and Benson Honig. 2003. "The Role of Social and Human Capital among Nascent Entrepreneurs.” Journal of Business Venturing 18 (3): 301-31.

Davis, James H, Mathew R Allen, and H David Hayes. 2010. "Is Blood Thicker Than Water? A Study of Stewardship Perceptions in Family Business." Entrepreneurship Theory and Practice 34 (6): 1093-1116.

Dew, Jeffrey. 2008. "Themes and Trends of Journal of Family and Economic Issues: A Review of Twenty Years (1988-2007)." Journal of Family and Economic Issues 29 (3). Springer US: 496-540.

Discua Cruz, Allan, Elias Hadjielias, and Carole Howorth. 2017. "Family Entrepreneurial Teams." In Research Handbook on Entrepreneurial Teams: Theory and Practice, edited by C. Ben-hafaiedh and T. Cooney, C. Ben-Haf. UK: Edward Edgar.

Discua Cruz, Allan, Eleanor Hamilton, and Sarah L Jack. 2012. "Understanding Entrepreneurial Cultures in Family Businesses: A Study of Family Entrepreneurial Teams in Honduras." Journal of Family Business Strategy 3 (3): 147-61.

Discua Cruz, Allan, Carole Howorth, and Eleanor Hamilton. 2013. "Intrafamily Entrepreneurship: The Formation and Membership of Family Entrepreneurial Teams." Entrepreneurship Theory and Practice 37 (1): 17-46.

Distelberg, Brian, and Adrian Blow. 2010. "The Role of Values and Unity in Family Businesses.” Journal of Family and Economic Issues 31 (4): 427-41.

Dyer, W Gibb. 2003. "The Family: The Missing Variable in Organizational Research.” Entrepreneurship Theory and Practice 27 (4): 401-16.

Dyer, W Gibb, Elizabeth Nenque, and E Jeffrey Hill. 2014. "Toward a Theory of Family Capital and Entrepreneurship: Antecedents and Outcomes." Journal of Small Business Management 52 (2): 266-85.

Eby, Lillian T., Wendy J. Casper, Angie Lockwood, Chris Bordeaux, and Andi Brinley. 2005. "Work and Family Research in IO/OB: Content Analysis and Review of the Literature (1980-2002)." Journal of Vocational Behavior 66 (1): 124-97.

Elo, Maria, and Hanneleena Hieta. 2016. "From Ethnic Enclaves to Transnational Entrepreneurs: The American Dream of the Finns in Oregon, USA." International Journal of Entrepreneurship and Small Business, forthcoming.

Ensley, Michael D, and Allison W Pearson. 2005. “An Exploratory Comparison of the Behavioral Dynamics of Top Management Teams in Family and Nonfamily New Ventures: Cohesion, Conflict, Potency, and Consensus." Entrepreneurship Theory and Practice 29 (3): $267-84$.

Fairlie, Robert W, and Alicia Robb. 2007. "Families, Human Capital, and Small Business: Evidence from the Characteristics of Business Owners Survey." Industrial \& Labor 
Relations Review 60 (2): 225-45.

Garcés-Galdeano, Lucía, Martín Larraza-Kintana, Carmen García-Olaverri, and Marianna Makri. 2016. "Entrepreneurial Orientation in Family Firms: The Moderating Role of Technological Intensity and Performance." International Entrepreneurship and Management Journal 12 (1): 27-45.

Gupta, Vipin, and Nancy Levenburg. 2010. "A Thematic Analysis of Cultural Variations in Family Businesses: The CASE Project.” Family Business Review 23 (2): 155-69.

Habbershon, Timothy G., Mattias Nordqvist, and Thomas M Zellweger. 2010. "Transgenerational Entrepreneurship." In Transgenerational Entrepreneurship. Exploring Growth and Performance in Family Firms across Generations, edited by Mattias Nordqvist and Thomas M Zellweger, 1-38. UK: Edward Elgar Publishing.

Habbershon, Timothy G, and Joseph Pistrui. 2002. "Enterprising Families Domain: FamilyInfluenced Ownership Groups in Pursuit of Transgenerational Wealth." Family Business Review 15 (3): 223-37.

Hamilton, Eleanor, Allan Discua Cruz, and Sarah Jack. 2017. "Re-Framing the Status of Narrative in Family Business Research: Towards an Understanding of Families in Business." Journal of Family Business Strategy 8 (1): 3-12.

Heck, R, S Danes, Margaret A Fitzgerald, G Haynes, C Jasper, Holly Schrank, Kathryn Stafford, and M Winter. 2006. "The Family's Dynamic Role within Family Business Entrepreneurship." In Handbook of Research on Family Business, edited by Panikkos Poutziouris, Kosmas Smyrnios, and Sabine Klein, 80-124. Cheltenham, UK: Edward Elgar.

Hoffman, James, Mark Hoelscher, and Ritch Sorenson. 2006. "Achieving Sustained Competitive Advantage: A Family Capital Theory." Family Business Review 19 (2): 135-45.

Howorth, Carole, Jacqueline Jackson, and Allan Discua Cruz. 2014. "Entrepreneurship in Family Businesses." In Handbook of Research in Small Business and Entrepreneurship, edited by E Chell and M Karatas-Ozkan, 333-57. Edward Elgar.

Howorth, Carole, Mary Rose, Eleanor Hamilton, and Paul Westhead. 2010. "Family Firm Diversity and Development: An Introduction." International Small Business Journal 28 (5): 437-51.

Hoy, Frank, and Trudy G Verser. 1994. "Emerging Business, Emerging Field: Entrepreneurship and the Family Firm.” Entrepreneurship, Theory and Practice 19 (1): 9-23.

Iacobucci, Donato, and Peter Rosa. 2010. "The Growth of Business Groups by Habitual Entrepreneurs: The Role of Entrepreneurial Teams." Entrepreneurship Theory and Practice 34 (2): 351-77.

Ivanova, Yuliya V. 2009. “Can This Business Be Rescued?” Entrepreneurship Theory and Practice 33 (4): 989-95.

Jack, Sarah L. 2005. "The Role, Use and Activation of Strong and Weak Network Ties: A Qualitative Analysis*." Journal of Management Studies 42 (6): 1233-59. 
Jaskiewicz, Peter, James G Combs, and Sabine B Rau. 2015. "Entrepreneurial Legacy: Toward a Theory of How Some Family Firms Nurture Transgenerational Entrepreneurship." Journal of Business Venturing 30 (1): 29-49.

Jaskiewicz, Peter, James Combs, Kristen Shanine, and Micki Kacmar. 2017. "Introducing the Family: A Review of Family Science with Implications for Management Research." Academy of Management Annals 11 (1): 309-41.

Jennings, J. E., R. S. Breitkreuz, and A. E. James. 2014. "Theories from Family Science: A Review Roadmap for Family Business Research.” In The SAGE Handbook of Family Business, edited by Leif Melin, Mattias Nordqvist, and Pramodita Sharma, 25-46. London: Sage Publications.

Johannisson, Bengt. 2003. "Entrepreneurship as a Collective Phenomenon.” In Entrepreneurship, edited by E Genesca, D Urbano, J Cappelleras, C Guallarte, and J Verges, 87-109. Bellaterra: UAB publications.

Kaslow, Florence. 1993. "The Lore and Lure of Family Business.” American Journal of Family Therapy 21 (1): 3-16.

Kellermanns, Franz W., and Kimberly A Eddleston. 2006. "Corporate Entrepreneurship in Family Firms: A Family Perspective.” Entrepreneurship Theory and Practice 30 (6): 80930 .

Khavul, S, G D Bruton, and E Wood. 2009. "Informal Family Business in Africa." Entrepreneurship Theory and Practice 33 (6): 1219-38.

Kidwell, Roland E, Frank Hoy, and Santiago Ibarreche. 2012. "'Ethnic' Family Business or Just Family Business? Human Resource Practices in the Ethnic Family Firm." Journal of Family Business Strategy 3 (1): 12-17.

Koerner, A F, and M A Fitzpatrick. 2004. "Communication in Intact Families." In The Handbook of Family Communication, edited by A L Vangelisti, 177-95. Mahwah, NJ: Lawrence Erlbaum.

Lansberg, Ivan, and Joseph H Astrachan. 1994. "Influence of Family Relationships on Succession Planning and Training: The Importance of Mediating Factors." Family Business Review 7 (1): 39-59.

Litz, R A. 2008. "Two Sides of a One-Sided Phenomenon: Conceptualizing the Family Business and Business Family as a Mobius Strip.” Family Business Review 21 (3): 217-36.

Lubatkin, Michael H., W S. Schulze, Yan A N Ling, and Richard N. Dino. 2005. "The Effects of Parental Altruism on the Governance of Family-Managed Firms." Journal of Organizational Behavior 26 (3): 313-30.

Marchisio, G, P Mazzola, S Sciascia, M Miles, and J Astrachan. 2010. "Corporate Venturing in Family Business: The Effects on the Family and Its Members." Entrepreneurship \& Regional Development 22 (3-4). Routledge: 349-77.

Mckie, Linda, Sarah Cunningham-Burley, and John Mckendrick. 2005. "Families and Relationships: Boundaries and Bridges.” In In Families in Society, 1-18. Bristol: The policy 
press.

Memili, Esra, Kimberly A Eddleston, Franz W Kellermanns, Thomas M Zellweger, and Tim Barnett. 2010. "The Critical Path to Family Firm Success through Entrepreneurial Risk Taking and Image.” Journal of Family Business Strategy 1 (4): 200-209.

Michael-Tsabari, Nava, Rania Labaki, and Ramona Kay Zachary. 2014. "Toward the Cluster Model The Family Firm's Entrepreneurial Behavior Over Generations." Family Business Review 27 (2): 161-85.

Nicholson, Nigel. 2015. "Primal Business: Evolution, Kinship and the Family Firm." In The Biological Foundations of Organizational Work, Stephen M., 237-67. Chicago and London: The University of Chicago Press.

Nordqvist, Mattias, and Leif Melin. 2010. "Entrepreneurial Families and Family Firms." Entrepreneurship and Regional Development 22 (3-4): 211-39.

Olson, David H. 2000. "Circumplex Model of Marital and Family Sytems.” Journal of Family Therapy 22 (2). Blackwell Publishers Ltd: 144-67.

Patel, Pankaj C, and James O Fiet. 2011. "Knowledge Combination and the Potential Advantages of Family Firms in Searching for Opportunities." Entrepreneurship Theory and Practice 35 (6): 1179-97.

Perez Rodriguez, M.J., and Rodrigo Basco. 2011. "The Cognitive Legitimacy of the Family Business Field." Family Business Review 24 (4).

Perez Rodriguez, M.J., Rodrigo Basco, María José Pérez Rodríguez, Rodrigo Basco, M.J. Perez Rodriguez, and Rodrigo Basco. 2011. "The Cognitive Legitimacy of the Family Business Field." Family Business Review 24 (4): 322-42.

Pérez Rodríguez, María José, and Rodrigo Basco. 2011. "The Cognitive Legitimacy of the Family Business Field.” Family Business Review 24 (4): 322-42.

Pieper, Torsten M. 2010. "Non Solus: Toward a Psychology of Family Business.” Journal of Family Business Strategy 1 (1): 26-39.

Rodriguez, Peter, Christopher S Tuggle, and Sean M Hackett. 2009. “An Exploratory Study of How Potential 'Family and Household Capital' Impacts New Venture Start-Up Rates." Family Business Review 22 (3): 259-72.

Rogoff, Edward G, and Ramona K Z Heck. 2003. "Evolving Research in Entrepreneurship and Family Business: Recognizing Family as the Oxygen That Feeds the Fire of Entrepreneurship.” Journal of Business Venturing 18 (5): 559-66.

Rosa, Peter, Carole Howorth, and Allan Discua Cruz. 2014. "Habitual and Portfolio Entrepreneurship and the Family in Business." In The SAGE Handbook of Family Business, edited by L Melin, Mattias Nordqvist, and P Sharma, SAGE, 364-82. London: Sage.

Rubin, Mark B. 2005. "Family Wealth: Keeping It in the Family." Family Business Review 18 (2): 173-77.

Schjoedt, Leon, Erik Monsen, Allison Pearson, Tim Barnett, and James J Chrisman. 2013. “New 
Venture and Family Business Teams: Understanding Team Formation, Composition, Behaviors, and Performance." Entrepreneurship Theory and Practice 37 (1): 1-15.

Schmitt-Rodermund, Eva. 2004. "Pathways to Successful Entrepreneurship: Parenting, Personality, Early Entrepreneurial Competence, and Interests.” Journal of Vocational Behavior 65 (3): 498-518.

Sciascia, Salvatore, Mattias Nordqvist, Pietro Mazzola, and Alfredo De Massis. 2015. "Family Ownership and R\&D Intensity in Small- and Medium-Sized Firms." Journal of Product Innovation Management 32 (3): 349-60.

Sharma, Pramodita, and James J Chrisman. 1999. "Toward a Reconciliation of the Definitional Issues in the Field of Corporate Entrepreneurship*." Entrepreneurship Theory and Practice 23 (3): 11-27.

Sharma, Pramodita, and Gregory P Irving. 2005. "Four Bases of Family Business Successor Commitment: Antecedents and Consequences." Entrepreneurship Theory and Practice 29 (1): 13-33.

Shepherd, Dean A. 2016. "An Emotions Perspective for Advancing the Fields of Family Business and Entrepreneurship: Stocks, Flows, Reactions, and Responses." Family Business Review 29 (2): 151-58.

Shepherd, Dean A, and Holger Patzelt. 2017. "Researching at the Intersection of Family Business and Entrepreneurship." In Trailblazing in Entrepreneurship: Creating New Paths for Understanding the Field, 181-208.

Short, Jeremy C, G Tyge Payne, Keith H Brigham, G T Lumpkin, and J Christian Broberg. 2009. "Family Firms and Entrepreneurial Orientation in Publicly Traded Firms A Comparative Analysis of the S\&P 500." Family Business Review 22 (1): 9-24.

Siebels, Jan-Folke, and Dodo zu Knyphausen-Aufseß. 2012. "A Review of Theory in Family Business Research: The Implications for Corporate Governance." International Journal of Management Reviews 14 (3): 280-304.

Smith, S. K., R. Hamon, R, B. B. Ingoldsby, and J. E. Miller. 2009. Exploring Family Theories. Oxford Uni. New York.

Stamm, Isabell K. 2016. "Coordination Tasks and Negotiation Modes of Linked Lives in Entrepreneurial Families.” Journal of Marriage \& Family 78 (4): 939-56.

Stangej, Olga, and Rodrigo Basco. 2017. "The Entrepreneurial Role of Families in Transitional Economies.” In Entrepreneurship in Transition Economies. Diversity, Trends, and Perspective, edited by Arnis Sauka and Alexander Chepurenko, forthcoming. Springer.

Steier, Lloyd. 2007. "New Venture Creation and Organization: A Familial Sub-Narrative." Journal of Business Research 60 (10): 1099-1107.

Stewart, Alex. 2003. "Help One Another, Use One Another: Toward an Anthropology of Family Business\$." Entrepreneurship Theory and Practice 27 (4): 383-96.

Stough, Roger, Friederike Welter, Joern Block, Karl Wennberg, and Rodrigo Basco. 2015. 
"Family Business and Regional Science: 'Bridging the Gap." Journal of Family Business Strategy 6 (4): 208-18.

Ucbasaran, Deniz, Andy Lockett, Mike Wright, and Paul Westhead. 2003. "Entrepreneurial Founder Teams: Factors Associated with Member Entry and Exit." Entrepreneurship Theory and Practice 28 (2): 107-28.

Uhlaner, Lorraine M. 2006. "Business Family as a Team: Underlying Force for Sustained Competitive Advantage." In Handbook of Research on Family Business, edited by Panikkos Poutziouris, Kosmas Smyrnios, and Sabine Klein, 125-44. Cheltenham, UK: Edward Elgar.

Uhlaner, Lorraine M., Franz Kellermanns, Kimberly Eddleston, and Frank Hoy. 2012. "The Entrepreneuring Family: A New Paradigm for Family Business Research.” Small Business Economics 38 (1): 1-11.

Van Auken, Howard, and James Werbel. 2006. "Family Dynamic and Family Business Financial Performance: Spousal Commitment." Family Business Review 19 (1): 49-63.

Vega Solano, Marco, and Allan Discua Cruz. 2017. "Daring to Be Different: A Case Study of Entrepreneurial Stewardship in a Guatemalan Family's Coffee Farm.” In Contextualizing Entrepreneurship, Ramirez-P. Edward Edgar.

von Schlippe, Arist, and Hermann Frank. 2013. "The Theory of Social Systems as a Framework for Understanding Family Businesses." Family Relations 62 (3): 384-98.

_ 2017. "Conflict in Family Business in the Light of Systems Theory." In Family Business Companion, edited by Edward Elgar, 367-84. Boston (Mass.).

von Schlippe, Arist, A. Schneewind, and K Schneewind. 2014. "Theories from Family Psychology and Family Therapy." In The SAGE Handbook of Family Business, edited by L Melin, M Nordqvist, and P Sharma, 47-. London: Sage Publications.

Welter, Friederike. 2011. "Contextualizing Entrepreneurship-Conceptual Challenges and Ways Forward." Entrepreneurship Theory and Practice 35 (1): 165-84.

Westhead, P, M Wright, and D Ucbasaran. 2001. "The Internationalization of New and Small Firms: A Resource-Based View." Journal of Business Venturing 16 (4): 333-58. http://www.scopus.com/inward/record.url?eid=2-s2.014344270210\&partnerID=40\&md5=ea8077bcf77c8028ef4eebf7e416a183.

Westhead, P, M Wright, D Ucbasaran, and F Martin. 2001. "International Market Selection Strategies of Manufacturing and Services Firms." Entrepreneurship and Regional Development 13 (1): 17-46.

Wiklund, Johan, Per Davidsson, David B Audretsch, and Charlie Karlsson. 2011. "The Future of Entrepreneurship Research.” Entrepreneurship Theory and Practice 35 (1): 1-9.

Winter, M, S M Danes, S K Koh, K Fredericks, and J J Paul. 2004. "Tracking Family Businesses and Their Owners over Time: Panel Attrition, Manager Departure and Business Demise." Journal of Business Venturing 19 (4): 535-59.

Wright, Mike, and Iris Vanaelst. 2009. "Introduction." In Entrepreneurial Teams and New 
Business Creation, edited by Mike Wright and Iris Vanaelst, 13:iix-xli. Cheltenham, UK: Edward Elgar Publishing Limited. 
Table 1. Schools of thought

\begin{tabular}{|c|c|c|c|c|}
\hline $\begin{array}{c}\text { School of thoughts } \\
\text { Authors }\end{array}$ & Aim and main concepts & Approach & Level of analysis & Assumption \\
\hline $\begin{array}{l}\text { Entrepreneurship by } \\
\text { families } \\
\text { Habbershon and Pistrui (2002) } \\
\text { Uhlaner et al. (2012) } \\
\text { Hamilton, Discua Cruz \& Jack } \\
\text { (2017) }\end{array}$ & $\begin{array}{l}\text { Enterprising family is a particular type of } \\
\text { family who has family as investor mind- } \\
\text { set and entrepreneurial strategic methods } \\
\text { Wealth creation across generations. } \\
\text { Transgenerational wealth as a continuous } \\
\text { stream of wealth that spans generations } \\
\text { Family ownership and its impact on } \\
\text { corporate entrepreneurship }\end{array}$ & $\begin{array}{l}\text { Entrepreneurial approach } \\
\text { Family theories } \\
\text { Portfolio entrepreneurship }\end{array}$ & $\begin{array}{l}\text { Family owner } \\
\text { Family as a team } \\
\text { Family as an investor }\end{array}$ & $\begin{array}{l}\text { Agency efficiencies } \\
\text { Family ownership group develop } \\
\text { entrepreneurial characteristics in } \\
\text { order to maintain and increase } \\
\text { wealth } \\
\text { Family with entrepreneurial } \\
\text { objectives and motives }\end{array}$ \\
\hline $\begin{array}{l}\text { Embedded family } \\
\text { entrepreneurship } \\
\text { Aldrich and Cliff (2003) } \\
\text { Shepherd and Patzelt (2017) }\end{array}$ & $\begin{array}{l}\text { Family embeddedness perspective on } \\
\text { entrepreneurship "implies that } \\
\text { researchers need to include family } \\
\text { dimensions in their conceptualization and } \\
\text { modeling, their sampling and analyzing, } \\
\text { and their interpretation and implications. }\end{array}$ & $\begin{array}{l}\text { Entrepreneurial approach by } \\
\text { adding the family dimension } \\
\text { - sociological perspective to } \\
\text { capture family changes } \\
\text { overtime - psychological } \\
\text { perspective to capture } \\
\text { emotions, conflict }\end{array}$ & $\begin{array}{l}\text { Firm and family level } \\
\text { Individual level }\end{array}$ & $\begin{array}{l}\text { Two social institutions are } \\
\text { linked } \\
\text { Holistic perspective } \\
\text { Family effect on entrepreneurial } \\
\text { process: new business } \\
\text { opportunities (opportunity } \\
\text { recognition), new business } \\
\text { venture (venture creation and } \\
\text { resource mobilization) }\end{array}$ \\
\hline $\begin{array}{l}\text { Entrepreneurship across } \\
\text { generations } \\
\text { Habbershon, Nordqvist, \& } \\
\text { Zellweger (2010) } \\
\text { Jaskiewicz, Combs, \& Rau (2015) }\end{array}$ & $\begin{array}{l}\text { Corporate entrepreneurship in the context } \\
\text { of family business and business family - } \\
\text { Studying family business through the } \\
\text { lenses of entrepreneurship } \\
\text { Transgenerational entrepreneurship } \\
\text { attempt to "address the true nexus } \\
\text { between entrepreneurship theory and } \\
\text { business family studies as an appropriate } \\
\text { way to examine and understand the role } \\
\text { and influence of the family in reaching } \\
\text { entrepreneurial, financial, and social } \\
\text { performance". }\end{array}$ & $\begin{array}{l}\text { Entrepreneurial approach } \\
\text { Family Theories } \\
\text { Family business literature } \\
\text { Business and strategic } \\
\text { management perspective }\end{array}$ & Family and firm level & $\begin{array}{l}\text { Family as a context to study } \\
\text { corporate entrepreneurship } \\
\text { Entrepreneurship as a key to } \\
\text { perform and success over several } \\
\text { generations }\end{array}$ \\
\hline
\end{tabular}


Table 2. Research questions

\begin{tabular}{|c|c|c|c|}
\hline & Entrepreneurship by families & Embedded family entrepreneurship & Entrepreneurship across generations \\
\hline Individual level & $\begin{array}{l}\text { How are resources allocated to family members } \\
\text { for entrepreneurial pursuits over time? } \\
\text { What kind of interactions, goals and patterns do } \\
\text { families develop to nurture individual } \\
\text { entrepreneurial behavior? } \\
\text { How does family members produce and re- } \\
\text { produce individual entrepreneurial behaviors } \\
\text { over time? }\end{array}$ & $\begin{array}{l}\text { How do individual resources contribute to the } \\
\text { action of enterprising families over time? } \\
\text { What kind of interactions, goals and patterns do } \\
\text { family members develop to nurture enterprising } \\
\text { families? } \\
\text { How do family members produce and re-produce } \\
\text { enterprising families over time? }\end{array}$ & $\begin{array}{l}\text { What individual factors in family members } \\
\text { contribute to entrepreneurship across } \\
\text { generations? } \\
\text { What kind of interactions, goals, and patterns do } \\
\text { family members develop to nurture habitual and } \\
\text { corporate entrepreneurship over time? } \\
\text { How do family members produce and re-produce } \\
\text { particular patterns to develop and sustain habitual } \\
\text { and corporate entrepreneurship over time? }\end{array}$ \\
\hline Group level & $\begin{array}{l}\text { How does embeddedness influence the cohesion } \\
\text { of family entrepreneurial teams over time? } \\
\text { What are the group level interactions, goals and } \\
\text { patterns that boost or hinder family group level of } \\
\text { entrepreneurship? } \\
\text { How does a family perspective on } \\
\text { entrepreneurship influence the collaboration } \\
\text { between several families in business (e.g. } \\
\text { cooperatives, industrial districts)? }\end{array}$ & $\begin{array}{l}\text { Are there different types of enterprising families } \\
\text { based on family embeddedness? } \\
\text { What are the group level interactions, goals and } \\
\text { patterns that boost or hinder enterprising } \\
\text { families? } \\
\text { How do groups of family members produce and } \\
\text { re-produce enterprising families? }\end{array}$ & $\begin{array}{l}\text { What group level factors can contribute to } \\
\text { effective intergenerational teams sustain } \\
\text { entrepreneurship across generations? } \\
\text { What are the group level interactions, goals and } \\
\text { patterns that boost or hinder corporate or habitual } \\
\text { entrepreneurship by family members over time? } \\
\text { How do several generations of a family in } \\
\text { business ensure entrepreneurial sustainability? }\end{array}$ \\
\hline Firm level & $\begin{array}{l}\text { How and when the three perspectives of family } \\
\text { (structural, psychosocial, and transactional) affect } \\
\text { family-based economic and entrepreneurial } \\
\text { activities? }\end{array}$ & $\begin{array}{l}\text { How do enterprising families affect family-based } \\
\text { economic and entrepreneurial activities? } \\
\text { How does family-firm relationship produce and } \\
\text { re-produce enterprising families? }\end{array}$ & $\begin{array}{l}\text { What is the relationship between generational } \\
\text { involvement and corporate entrepreneurship in } \\
\text { family businesses? } \\
\text { What kind of interactions do firms internally } \\
\text { develop to nurture transgenerational } \\
\text { entrepreneurship? }\end{array}$ \\
\hline Contextual dimensions & $\begin{array}{l}\text { How do contexts determine and affect } \\
\text { entrepreneurial actions by families? } \\
\text { How do institutional, cultural, and family } \\
\text { contexts boost or retard entrepreneurial actions by } \\
\text { families? }\end{array}$ & $\begin{array}{l}\text { Is the family a particular micro-context for } \\
\text { entrepreneurship? } \\
\text { How do contexts mediate and moderate the } \\
\text { relationship between family and } \\
\text { entrepreneurship? }\end{array}$ & $\begin{array}{l}\text { Do contexts matter for corporate or habitual } \\
\text { entrepreneurship over time? } \\
\text { How do contexts interact with corporate } \\
\text { entrepreneurship and family generations? }\end{array}$ \\
\hline Time dimensions & $\begin{array}{l}\text { What is the relationship between family life cycle } \\
\text { and entrepreneurial actions by families? } \\
\text { How time and what time-dimensions do affect } \\
\text { family and entrepreneurial? }\end{array}$ & $\begin{array}{l}\text { What is the role that time plays in the family } \\
\text { effect on entrepreneurship? }\end{array}$ & $\begin{array}{l}\text { Does the way family and societal culture interpret } \\
\text { time affect corporate entrepreneurship? }\end{array}$ \\
\hline
\end{tabular}

